\title{
Editorial
}

\section{Cadernos Nietzsche completam 20 anos}

Os Cadernos Nietzsche estão completando, em 2016, 20 anos. Em 1996, ao lado dos Encontros Nietzsche, o periódico começou a ser publicado como uma das atividades do Grupo de Estudos Nietzsche - GEN. Fundado por Scarlett Marton, o grupo tem efetivamente contribuído para o avanço da pesquisa Nietzsche no Brasil. Não apenas com a publicação dos Cadernos Nietzsche, que trazem todas as linhas interpretativas do pensamento nietzschiano, da coleção Sendas \& Veredas, que publica ensaios, mas também textos de outro caráter, como o Dicionário Nietzsche, ou com os Encontros Nietzsche, que trazem, por sua vez, renomados pesquisadores nacionais e estrangeiros para expor seus trabalhos entre nós, mas igualmente tem dado sua contribuição com os resultados das pesquisas realizadas pelos seus membros. No que tange a este último ponto, salta aos olhos a diferença do patamar da pesquisa em Nietzsche no Brasil décadas atrás do estado que a encontramos atualmente. Nesse aspecto, os Cadernos Nietzsche deram uma importante contribuição à pesquisa Nietzsche em nosso país, haja vista a qualidade que sempre buscou alcançar e, não apenas isso, preservar. Se a revista passou por importantes modificações ao longo dessas duas décadas, os objetivos que sempre a guiaram continuam os mesmos.

É digno de nota que, nesse percurso, houve uma ampliação do número de artigos publicados, bem como de formas de divulgação. Dos 10 artigos anuais das primeiras edições, passamos a publicar o mínimo de 25. Além disso, à versão impressa, acrescentamos a versão eletrônica, que pode ser acessada tanto na nossa pá- 
gina hospedado na Unifesp, quanto na base de dados Scielo. Para adaptarmo-nos às regras desse mesmo banco de dados, os Cadernos passaram a ter 3 edições anuais. Ocupando um bom lugar desde as primeiras avaliações da CAPES, a revista atingiu o estrato mais alto do Qualis: o Al. Se se pode considerar bem-sucedida esta trajetória, ela não teria sido possível sem a liderança de Scarlett Marton, tampouco sem a atuação dos diversos membros do GEN. Há, pois, todo um trabalho de contato com autores, recepção de textos, pareceres, tradução, revisão, envio, atualização dos endereços eletrônicos que sempre estiveram sob a responsabilidade do grupo. Os Cadernos Nietzsche são, sem dúvida, o resultado de um trabalho conjunto de pessoas que compartilham de "vivências comuns".

Um panorama da atuação e dos resultados do GEN nestes 25 anos de sua atuação, bem como dos 20 anos dos Cadernos Nietzsche, nos é apresentado por Scarlett Marton, cujo artigo "GEN - Grupo de Estudos Nietzsche - 25 anos" abre esta edição. O Dossiê "Recepção: Nietzsche no Brasil: núcleo histórico, parte V" contém os nove textos que, em conjunto com os outros nove publicados na edição anterior, integram a pesquisa "Nietzsche no Brasil (1933-1943): da ascensão do nacional-socialismo ao Grande Reich Alemão", coordenada pelo professor Luís Eduardo Rubira, da Universidade Federal de Pelotas (Ufpel) e membro do Grupo de Estudos Nietzsche (GEN). Uma análise desse conjunto de dezoito textos nos é apresentada pelo autor da pesquisa, em artigo escrito com o mesmo título, e que antecede os textos do próprio dossiê. Para finalizar esta edição, Stefano Busellato resenha o livro de Giuliano Campioni, Nietzsche e o espírito latino, publicado pela coleção Sendas \& veredas (2016).

\section{Ivo da Silva Jr./Márcio José Silveira Lima Editores-Responsáveis}

